\title{
Ethnic Enclaves and the Dynamics of Social Identity on the College Campus: The Good, the Bad, and the Ugly
}

\section{Citation}

Sidanius, James, Colette Van Laar, Shana Levin, and Stacey Sinclair. 2004. Ethnic enclaves and the dynamics of social identity on the college campus: The good, the bad, and the ugly. Journal of Personality and Social Psychology 87(1): 96-110.

\section{Published Version}

http://dx.doi.org/10.1037/0022-3514.87.1.96

\section{Permanent link}

http://nrs.harvard.edu/urn-3:HUL.InstRepos:3205411

\section{Terms of Use}

This article was downloaded from Harvard University's DASH repository, and is made available under the terms and conditions applicable to Other Posted Material, as set forth at http:// nrs.harvard.edu/urn-3:HUL.InstRepos:dash.current.terms-of-use\#LAA

\section{Share Your Story}

The Harvard community has made this article openly available.

Please share how this access benefits you. Submit a story.

\section{Accessibility}




\title{
Ethnic Enclaves and the Dynamics of Social Identity on the College Campus: The Good, the Bad, and the Ugly
}

\author{
Jim Sidanius \\ University of California, Los Angeles \\ Shana Levin \\ Claremont McKenna College
}

\author{
Colette Van Laar \\ Leiden University \\ Stacey Sinclair \\ University of Virginia
}

\begin{abstract}
The effects of membership in ethnic organizations and fraternities and sororities on intergroup attitudes were examined using a 5-wave panel study at a major, multiethnic university. The results showed that these effects were similar for both minority and White students. Membership in ethnic student organizations for minorities and Greek organizations for Whites was anteceded by the degree of one's ethnic identity, and the effects of membership in these groups were similar, although not identical, for both White and minority students. These effects included an increased sense of ethnic victimization and a decreased sense of common identity and social inclusiveness. Consistent with social identity theory, at least a portion of these effects were mediated by social identity among both White and minority students.
\end{abstract}

Recent American history has witnessed a dramatic increase in the degree of racial and ethnic diversity on university campuses (Hughes, 1992). However, rather than this increased ethnic heterogeneity leading to a broad intermixing and blending of different cultures and ethnic traditions on campuses, it has led, a number of observers have remarked, to the tendency for students from different ethnic groups to remain relatively segregated and isolated from one another (e.g., Broadway \& Flesch, 2000; Crisostomo, 2001; McDermott, 2002). It is often claimed that one of the factors contributing to this continuing ethnic and racial segregation on the American campus is the prevalence of ethnic and racial student organizations, primarily consisting of member students from minority groups. A number of observers have argued that such organizations are destructive to the creation of a common student identity and merely serve to maintain and even exacerbate ethnic tension, as well as to maintain the alienation and isolation of minority groups on campus (e.g., Chavez, 1982; D'Souza, 1991). In contrast, and using what could be regarded as the "multicultural perspective," others have argued that rather than increasing levels

Jim Sidanius, Department of Psychology, University of California, Los Angeles; Colette Van Laar, Department of Psychology, Leiden University, Leiden, the Netherlands; Shana Levin, Department of Psychology, Claremont McKenna College; Stacey Sinclair, Department of Psychology, University of Virginia.

This research was supported by grants from the Russell Sage Foundation and the University of California, Los Angeles, Office of the Chancellor and by National Science Foundation Award BCS-9808686. Special thanks are due to David Sears and Marilynn Brewer for their collaboration on this joint research project and to Michael Greenwell for his efforts in data collection.

Correspondence concerning this article should be addressed to Jim Sidanius, Department of Psychology, University of California, Los Angeles, 405 Hilgard Avenue, Los Angeles, CA 90024. E-mail: sidanius@ psych.ucla.edu of ethnic and racial isolation and tension, ethnically oriented student organizations help provide minority students with a safe harbor and social support system from which to reach out to the larger campus community and to members of other ethnic communities (see, e.g., Hurtado, Milem, Clayton-Pedersen, \& Allen, 1999; Treviño, 1992).

The little empirical work that has been done on this question suggests that students join minority racial and/or ethnic organizations for the purpose of identity enhancement, and increased comfort with one's identity may, in turn, lead to greater interest in cross-cultural contacts, a greater sense of belonging to the university community, and greater integration into broader campus life (see Ethier \& Deaux, 1994; Hurtado, 1993; Hurtado, Dey, \& Treviño, 1994; Hurtado et al., 1999; LeCount, 1987; Mitchell \& Dell, 1992; Moran, Yengo, \& Algier, 1994; Reyes, 1997; Treviño, 1992). Along similar lines, Gilliard (1996) found that for Black students, participation in ethnically oriented activities was correlated with greater social involvement, greater social interactions with faculty, and greater use of support services at predominantly White institutions. However, whereas much of this earlier work has focused on the effects that minority ethnic organizations have on minority academic achievement (Gilliard, 1996), attrition rates (e.g., Reyes, 1997), and integration into campus life (e.g., Treviño, 1992), relatively little research has specifically focused on the broad effects of these student organizations on intergroup attitudes and behaviors (e.g., intergroup bias). Furthermore, many of these earlier studies used cross-sectional research designs or panel studies over relatively short time intervals. However, to the extent that this research appears to have implications for the effects of minority ethnic organizations on intergroup relations on campuses, these implications appear to support a multicultural, or pluralist, perspective (see e.g., Hurtado, Milem, Clayton-Pedersen, \& Allen, 1998). This is to say that participation in these ethnic organizations enables minority students to experience less threat to their social identities and feel a greater sense of inclusion in campus life, 
which, in the long run, contribute to greater intergroup contact and an improved intergroup atmosphere on campus.

Not only has much of this earlier research ignored the broad effects of student organizations on intergroup attitudes and/or been largely restricted to cross-sectional rather than longitudinal designs, but this work has also been largely descriptive rather than theoretical in focus (see Ethier \& Deaux, 1994, for an exception). Though rarely applied to the study of the effects of ethnic organizations on college campuses, modern theories of intergroup relations, such as social identity theory, should be able to make rather straightforward predictions as to what these effects should be. As is well known, the major theme of social identity theory has been broadly interpreted to mean that in-group identification is causally related to intergroup bias and intergroup discrimination (see, e.g., Duckitt, 1989; Hinkle \& Brown, 1990; Kelly, 1993). However, despite this widespread understanding of the in-groupidentification/intergroup-bias effect, a number of leading social identity theorists have recently argued that the causal link between in-group identification and intergroup bias obtains only under certain limiting conditions (see Reicher, in press; Turner, 1999). Turner (1999) argued that in-group identification is most likely to lead to intergroup bias when (a) the individual categorizes "the self" in terms of membership in the relevant group; (b) the social identity is salient with respect to some comparative judgment; (c) the in-group and out-group are perceived to be interrelated within an overall social structure; (d) the dimension of intergroup comparison is relevant to intergroup status relationships; and (e) the out-group is relevant to the particular comparative judgment being made. These are all conditions likely to be satisfied on the contemporary and multiethnic American campus.

Given the long-standing, intense, and often infected nature of ethnic and racial relationships within American society and the highly competitive and often racially flavored nature of the admissions process on American campuses (e.g., affirmative action debates), there is strong reason to believe that an ethnically diverse American university campus is a context within which one is very likely to find the identity-bias connection so often associated with social identity theory. Given the structural relationships among American ethnic and/or racial groups and those currently on multiethnic campuses in particular, the application of social identity theory would lead one to expect that-rather than generally improving the tenor of intergroup relations-activities that further increase the degree of racial and ethnic identities (e.g., ethnic organizations) may increase rather than decrease the amount of intergroup bias and intergroup tension found on the college campus. Consistent with the empirical findings of Ethier and Deaux (1994) and the logic of social identity theory, there is reason to believe that involvement in ethnically oriented student organizations results in the increased degree and importance of one's ethnic identity. This enhanced degree of ethnic identity, in turn, can contribute to higher levels of ethnic tension and intergroup bias. Thus, in direct contrast to the predictions of those supporting a pluralist or multiculturalist perspective, we theoretically expect that involvement in ethnically oriented student organizations will contribute to enhanced rather than attenuated levels of interethnic bias and conflict.

Furthermore, contrary to the current multicultural discourse, we argue that the pernicious effects of ethnic group membership is not restricted to those ethnic organizations favored by minority stu- dents (e.g., Black Student Union, Chinese American Student Organization) but will be equally operative for organizations mainly oriented toward the majority, European American, student body as well. Primary among such organizations are the fraternities and sororities belonging to the Greek system. The first college social fraternity with a Greek-letter name (i.e., Phi Beta Kappa) and a secret initiation ritual was established at William and Mary College in 1776 . The first nonsecret social fraternity began in 1825 at Union College in Schenectady, New York. In the 1870s these men's fraternities were joined by women's fraternities, which were called sororities. Although these fraternities and sororities were always exclusionist in both racial and socioeconomic terms, explicit discriminatory entrance requirements did not become widespread until the beginning of the 20th century. By 1928 more than half of the national fraternities and sororities had written rules and constitutions explicitly excluding applicants on the basis of religious affiliation and race. Furthermore, on a large number of American campuses, interfraternity councils admitted only White Christian fraternities and sororities to their membership (Lee, 1955a, 1955b). These explicitly discriminatory practices were not seriously challenged until the end of the Second World War. However, by the end of the 1970s, these exclusionary entrance requirements had all but disappeared from American universities.

Nonetheless, despite the removal of these explicitly discriminatory practices, many empirical studies suggest that ethnocentrism and generalized prejudice remain associated with Greek organizations. For example, in a 1-year longitudinal study among 3,331 incoming students at 18 colleges and universities, Pascarella, Edison, Nora, Hagedorn, and Terenzini (1996) found that belonging to a fraternity or sorority had a significant negative impact on openness to diversity among White students (but had a slightly positive impact among ethnic minority students). Similarly, in a study of 1,242 male freshmen at the University of Pennsylvania, Miller (1973) found that fraternity members were significantly less interested in issues concerning social justice than nonmembers (known in the literature as "independents"). Segal (1965) used a relatively small sample of students from a 4-year liberal arts college and found that fraternity members were significantly more anti-Semitic than nonmembers (see also Bohrnstedt, 1969; Fay \& Middleton, 1939; Glisan, 1992; Hurtado, 1990; Longino \& Kart, 1973; Muir, 1991; Plant, 1958; Scott, 1965; Wilder, Hoyt, Doren, Hauch, \& Zettle, 1978; see also Gist, 1955). Although most of the empirical evidence suggests that Greek affiliation is associated with higher levels of ethnocentrism, a few studies have failed to find evidence for this association. For example, a relatively recent panel study of undergraduates at a highly selective Eastern Ivy League university failed to find any evidence that Greek students were significantly more intolerant of homosexuality, more male dominant, less socially conscious, or less ideologically feminist than nonmembers (Lottes \& Kuriloff, 1994). Similarly, using a large sample from a Midwestern university, Plant (1958) found that Greek students were not significantly more ethnocentric than independents either when they entered college or at the end of 2 years of college (see also Hendricks, 1996; Wilder, Hoyt, Surbeck, Wilder, \& Carney, 1986). It is quite possible that these conflicting results are due to some complex combination of the precise measures of ethnocentrism used, the historical period in which the studies were conducted, and the ethnic heterogeneity and academic selectivity of the university being studied. 
Although these findings are mixed, they suggest that when exploring the effects of ethnically oriented student organizations, one should not restrict attention to ethnic organizations directed toward students from minority groups but should extend focus to include predominantly White student organizations within the Greek system as well. Therefore, unique to research in this area, in this study we examined the effects of both minority ethnic organizations among minorities and Greek organizations among Whites across a broad array of intergroup attitudes within the context of a highly diverse and selective university. The longitudinal design of the study allows us to control for preexisting differences in attitudes and perceptions between students, and it allows us to examine the net effect of membership in ethnic organizations on attitudes and perceptions in later years.

Finally, given the logic of social identity theory, we expect that at least part of the connection between organizational membership and intergroup attitudes (e.g., social distance, social policy attitudes) will be mediated by social identity. This is to say that membership in ethnically oriented student organizations increases the students' levels of ethnic identity, which in turn, alters intergroup attitudes such as intergroup bias, group-relevant social policy attitudes, and perceived zero-sum conflict between groups.

Therefore, given the logic of social identity theory, the conditions under which group identity is expected to be associated with in-group bias discussed previously (e.g., group identity, group salience, out-group relevance; see Turner, 1999), and the ethnic history of student organizations on the American campus, the contemporary, multiethnic American campus is a context within which the following four hypotheses should hold:

Although it is obvious that minority students tend to be overrepresented among the members of ethnic student organizations, Greek organizations (i.e., sororities and fraternities) will tend to have an overrepresentation of White students.

Although previous research has shown that precollege intergroup attitudes and ethnic identity are related to the decision to join ethnic organizations in college among minority students (see, e.g., Ethier \& Deaux, 1994), the decision to join Greek organizations will be related to precollege intergroup attitudes and ethnic identity among White students.

Membership in both ethnic organizations among minorities and Greek organizations among Whites will contribute to increased levels of ethnic in-group identification and to more negative attitudes vis-à-vis members of other ethnic groups.

To the extent that ethnic organizational membership among minorities and Greek organizational membership among Whites increase negative intergroup attitudes, these effects will be mediated by increased levels of ethnic identity.

\section{METHOD}

\section{Participants and Design}

The dataset consisted of a five-wave panel study of University of California, Los Angeles (UCLA) students. The first wave of data was collected during the beginning of the summer orientation program, before the actual start of college classes in the fall of 1996. All students who attended this summer orientation program were asked whether they wanted to participate in a multiwave study of student life and social attitudes on campus to be conducted once a year until the spring of $2000 .^{1}$

In 1996, 3,877 incoming freshmen enrolled at UCLA: 1,244 Whites, 1,410 Asian Americans, 710 Latinos, 244 Blacks, and 269 students of other ethnicities (including Native American and Middle Eastern) or unreported ethnicities (data are based on enrolled students during Week 1 of the Fall 1996 term). Approximately 95\% of these incoming freshmen (3,672 students) attended the 1996 summer orientation program. Of this number, 923 were not able to participate in the first wave because they were under 18 years of age and did not have written consent from their parents to participate. Therefore, the eligible population for the baseline wave of data collection consisted of 2,749 students. Seventy-eight percent (i.e., 2,157 students) of this eligible population agreed to participate and completed a written questionnaire administered during the summer orientation program.

All subsequent waves of the study were conducted by telephone interviews, which averaged $20 \mathrm{~min}$ in length and were conducted with a computer-assisted telephone interview system run by the Institute for Social Science Research at UCLA. Response rates for all five waves of data were as follows: $78 \%, 82 \%, 82 \%, 66 \%$, and $59 \%$. The current study examines only the responses of students in the four largest ethnic categories $(N=2,132)$ : White $(n=764)$, Asian $(n=758)$, Latino $(n=466)$, and Black $(n=144)$.

Because essentially the entire incoming class of 1996 was asked to participate in the study, it was clear that neither class members' organizational membership nor any other special criteria were used to select participants. We simply informed the entire entering class that we would like to study their progress through college and would be contacting them every spring.

The questionnaire administered consisted of a battery of questions concerning their social identities, their sociopolitical attitudes, the demographic characteristics of their instructors, the kinds of courses taken each year, the campus organizations they belonged to, and the nature of the extracurricular activities they were most actively involved with. Only a fraction of these questions are used for the study described here.

\section{Measures}

\section{Campus Organizations}

There were approximately 154 student organizations on the UCLA campus when data for the study were collected. We examined two particular types of student organizations: minority ethnic organizations and Greek organizations (sororities and fraternities). Minority ethnic organizations were identified as those groups whose names referred to a specific ethnic or racial minority group (e.g., United Cambodian Students, Sikh Students Association, Iranian Students Group, African Student Union) or whose membership consisted of $80 \%$ or more of a specific ethnic or racial group (i.e., Asian, Latino, or Black). Of those students belonging to one of the four major ethnic groups, 548 students, roughly $26 \%$ of the sample, were members of at least one such ethnic organization at some point in their college careers, whereas 1,584 students were never members of such an organization and were categorized as independents.

Three hundred twenty-four students, roughly $15 \%$ of the sample, were members of Greek organizations at some point in their college careers, whereas 1,808 students were never members of Greek organizations and were categorized as independents.

\footnotetext{
${ }^{1}$ We also collected a sixth wave of data in the spring of 2001 for students who had not graduated by the end of their 4th year, but it is not analyzed here.
} 


\section{Intergroup Attitudes}

For this study, we used 12 measures assessing intergroup attitudes, depending on the data wave, which we found convenient to classify into four conceptual clusters: (a) racial policy attitudes, (b) social identity attitudes, (c) ethnic prejudice, and (d) perceptions of intergroup conflict. Unless otherwise indicated, all measures were assessed with 7-point Likert scales, generally varying from 1 (strongly disagree) to 7 (strongly agree). ${ }^{2}$

\section{Cluster 1: Racial Policy Attitudes}

We assessed students' attitudes toward two public policies having either implicit or explicit ethnic or racial overtones: (a) affirmative action opposition and (b) opposition to ethnic diversity on campus.

Affirmative action opposition was indexed by reaction to three questions: (a) "Affirmative action admits too many students who have a low chance of academic success," (b) "Affirmative action is harmful to members of my ethnic group," and (c) "Affirmative action stigmatizes the people it's supposed to help." The average internal consistency reliability of this affirmative action scale across the five waves was reasonably high $(\alpha=.78)$

Opposition to ethnic diversity on campus was indexed by the question, "We should do what we can to increase ethnic diversity on campus." The item was scaled so that high scores implied greater opposition to ethnic diversity on campus.

\section{Cluster 2: Social Identity Attitudes}

Four different aspects of social identity were assessed: (a) ethnic identity, (b) ethnic activism, (c) common in-group identity, and (d) university identification.

Ethnic identity was assessed by the use of the following three measures: (a) "How important is your ethnicity to your identity?" $(1=$ not at all to 7 = very important), (b) "How often do you think of yourself as a member of your ethnic group?" ( 1 = not at all to 7 = very often $)$, (c) "How close do you feel to other members of your ethnic group?" $(1=$ not at all to $7=$ very close). The average reliability across the five waves of data was quite high for a three-item scale $(\alpha=.84) .^{3}$

Ethnic activism was measured with the root question: "How seriously have you considered participating in the following activities on behalf of your ethnic group?" The list of activities included (a) "voting in terms of what is good for your particular group," (b) "participating in demonstrations," and (c) "signing petitions." The answers to all three questions were given on a 7-point scale ranging from 1 (not at all seriously) to 7 (very seriously) (average $\alpha=.88$ ).

Common in-group identity, or the sense of all belonging to the same group, was assessed from the end of the freshman year forward. This construct was operationalized by the use of two questions: (a) "Despite the different groups at UCLA, there is frequently the sense that we are all just one group" and (b) "At UCLA it usually feels as though we belong to different groups" (reverse coded). The reliability across waves was again reasonably high (average $\alpha=.73$ ).

University identification was measured with two questions: (a) "How often do you think of yourself as a UCLA student?" $(1=$ not at all to $7=$ very often) and (b) "To what degree do you experience a sense of belonging or a sense of exclusion at UCLA?" $(1=$ exclusion to 7 = belonging $)$. A very strong sense of identification was coded as 7 and a very weak sense of identification was coded as 1 . The average reliability of this two-item scale was deemed to be adequate (average $\alpha=.57$ ).

\section{Cluster 3: Ethnic Prejudice}

We defined three different measures of ethnic prejudice, each analyzed separately: (a) intergroup bias, (b) miscegenation opposition, and (c) symbolic racism.
Intergroup bias was assessed by asking the students: "How positively or negatively do you feel toward the following groups?" (Caucasians/Whites, Latinos/Hispanics, Asians/Asian Americans, and African Americans/ Blacks; 1 = very negatively, 7 = very positively). In each year, intergroup bias was computed as the item measuring in-group affect minus the average of the three items measuring out-group affect.

Miscegenation opposition was defined by two statements about opposition to miscegenation. The items were (a) "Interethnic dating should be avoided" and (b) "Interethnic marriage should be avoided." The average reliability of this scale across the five waves of data was extremely high $(\alpha=.95)$.

Symbolic racism was defined by the use of a four-item scale in which participants were asked to rate the degree to which they agreed or disagreed (from $1=$ strongly disagree to $7=$ strongly agree) with the following statements (a) "Blacks are getting too demanding in their push for equal rights;" (b) "Over the past few years, Blacks have gotten less economically than they deserve" (reverse coded); (c) "The Irish, Italians, Jews, and many other minorities overcame prejudice and worked their way up. Blacks should do the same without special favors;" and (d) "Blacks get less attention from the government than they deserve" (reverse coded). The average reliability of this scale across the five waves of data was adequate $(\alpha=.65)$

\section{Cluster 4: Perceived Group Conflict}

The final cluster of scales assessed the students' perceptions of ethnic victimization and group conflict.

Ethnic victimization assessed the students' sense that they and the ethnic groups to which they belonged were the targets of ethnic discrimination. This victimization variable was defined as a composite of four questions: (a) "I experience discrimination at UCLA because of my ethnicity," (b) "Other members of my ethnic group experience discrimination on campus," (c) "Most of my professors don't have any ethnic prejudices" (reverse

\footnotetext{
${ }^{2}$ Although these variable clusters do not strictly conform to the results of empirical factor analyses, this organization of the variables is consistent with the manner in which they are usually conceptualized within the literature (see, e.g., Sears, Sidanius, \& Bobo, 2000).

${ }^{3}$ This ethnic identity scale was either identical to or nearly identical to other identity measures used in this literature (see, e.g., Ellemers, Van Knippenberg, De Vries, \& Wilke, 1988; Ellemers, Van Knippenberg, \& Wilke, 1990; Jetten, Spears, \& Manstead, 1996; Levin \& Sidanius, 1999; Levin, Sidanius, Rabinowitz, \& Federico, 1998; Sinclair, Sidanius, \& Levin, 1998; Sidanius, Feshbach, Levin, \& Pratto, 1997). As an additional check on the construct validity of this ethnic identity scale, we examined ethnic identity as a function of ethnic group and college tenure (between the freshman and senior years). Previous research has shown that European Americans tend to have relatively low levels of ethnic identity and ethnic minorities tend to have relatively high levels of ethnic identity, especially Black Americans (see, e.g., Yancey, Aneshensel, \& Driscoll, 2001). Use of an Ethnic Group $\times$ Tenure repeated analysis of variance showed ethnic group differences consistent with standard results in the literature, $F(3$, 717 ) $=90.82, \eta=.52$ (with no interaction between ethnic group and college tenure). This is to say that Whites had significantly lower levels of ethnic identity $(M=3.64)$ than all three major minority groups (i.e., Asians, Latinos, Blacks), whereas Blacks had significantly higher ethnic identity scores than all other ethnic groups $(M=5.72)$. Although Latinos had higher ethnic identity scores than Asians, these differences were not significantly different (i.e., 5.19 vs. 5.03 , respectively).
} 
coded), ${ }^{4}$ and (d) "Many professors at UCLA are biased against people of my ethnic group." 5 The entire scale was coded such that high scores imply high levels of perceived victimization. This scale was analyzed as a single construct, and its average reliability across the five waves of data was reasonably high $(\alpha=.73)$.

Ethnic organizations promote separatism. This variable was assessed with the following statement: "Ethnic student organizations at UCLA promote separatism," to which the students indicated their degree of agreement ranging from 1 (strongly disagree) to 7 (strongly agree).

Perceived zero-sum group conflict. This variable was assessed with the following statement: "More good jobs for other groups come at the expense of fewer good jobs for members of my group." The students indicated their agreement on a scale ranging from 1 (strongly disagree) to 7 (strongly agree).

\section{RESULTS}

\section{Distribution of Ethnic Groups Within Campus Organizations}

We began our analysis of these data by examining membership in the minority ethnic organizations (i.e., excluding fraternities and sororities) as a function of ethnicity (see Table 1). Not surprisingly, whereas very few Whites were members of traditional (minority) ethnic organizations (i.e., approximately $1.2 \%$ ), a very substantial proportion of Latinos (28.8\%), Asians (42.0\%) and, especially, Blacks $(60.4 \%)$ were members of ethnic organizations, $\chi^{2}(3, N=2,132)=438.58, p<.01, \varphi=.45$. The disproportionate distribution of the ethnic groups across the minority ethnic organizations can be more easily appreciated by inspection of the standardized residuals for each ethnicity by ethnic-organization category. Because these standardized residuals are essentially $z$ scores, they not only show whether the observed frequency within each cell is above or below what would be expected by chance, but also show whether that observed frequency deviates significantly from chance. Thus, we see that Blacks and Asian Americans are significantly underrepresented among nonmembers of minority ethnic organizations (i.e., standardized residuals $=-4.8$ and $-5.2, p<.01$, respectively), whereas they are very substantially overrepresented among members of minority ethnic organizations (i.e., standardized residuals $=8.2$ and 8.8, $p<.01$, respectively).

Turning our attention to the Greek organizations, we found that membership in fraternities and sororities was also unevenly distributed across the four ethnic groups (see Table $2 ; \chi^{2}[3, N=$ $2,132]=101.04, p<.01, \varphi=.22$ ). Inspection of the standardized

Table 1

Distribution of Membership in Minority Ethnic Organizations Across Ethnicity

\begin{tabular}{|c|c|c|c|c|c|}
\hline \multirow[b]{2}{*}{ Ethnic category } & \multicolumn{2}{|c|}{ Nonmember } & \multicolumn{2}{|c|}{ Member } & \multirow{2}{*}{$\begin{array}{l}\text { Total } \\
n(\%)\end{array}$} \\
\hline & $n(\%)$ & Res. & $n(\%)$ & Res. & \\
\hline White & $755(98.8)$ & 7.9 & $9(1.2)$ & -13.4 & 764 (100) \\
\hline Asian & $440(58)$ & -5.2 & $318(42)$ & 8.8 & $758(100)$ \\
\hline Latino & $332(71.2)$ & -0.8 & $134(28.8)$ & 1.3 & $466(100)$ \\
\hline Black & $57(39.6)$ & -4.8 & $87(60.4)$ & 8.2 & $144(100)$ \\
\hline Total & 1,584 & & 548 & & 2,132 \\
\hline
\end{tabular}

Note. $\quad \chi^{2}(3, N=2,132)=438.58, \phi=.45, p<.01$. Res $=$ standardized residual.
Table 2

Distribution of Fraternity and Sorority Membership Across Ethnicity

\begin{tabular}{|c|c|c|c|c|c|}
\hline \multirow[b]{2}{*}{ Ethnic category } & \multicolumn{2}{|c|}{ Non-Greek member } & \multicolumn{2}{|c|}{ Greek member } & \multirow{2}{*}{$\frac{\text { Total }}{n(\%)}$} \\
\hline & $n(\%)$ & Res. & $n(\%)$ & Res. & \\
\hline White & $568(74.3)$ & -3.1 & $196(25.7)$ & 7.4 & $764(100)$ \\
\hline Asian & $688(90.8)$ & 1.8 & $70(9.2)$ & -4.2 & $758(100)$ \\
\hline Latino & $418(89.7)$ & 1.1 & $48(10.3)$ & -2.7 & $466(100)$ \\
\hline Black & 134 (93.1) & 1.1 & $10(6.9)$ & -2.5 & $144(100)$ \\
\hline Total & 1,808 & & 324 & & 2,132 \\
\hline
\end{tabular}

Note. $\quad \chi^{2}(3, N=2,132)=101.04, \phi=.22, p<.01$. Res $=$ standardized residual.

residuals in each cell of Table 2 shows that White students were significantly underrepresented among nonmembers of sororities and fraternities (standardized residual $=-3.1, p<.01$ ) and significantly and substantially overrepresented among the members of these Greek organizations (standardized residual $=7.4$, $p<.01)$. The exact opposite pattern was found for all three of the major minority groups (i.e., Asians, Latinos, and Blacks). All three minority groups had a slight tendency to be overrepresented in the nonmember category (i.e., standardized residuals $=1.8,1.1$, and 1.1 , respectively), and all three groups were significantly underrepresented in the member category (i.e., standardized residuals $=$ $-4.2,-2.7$, and -2.5 , respectively).

Altogether, these results suggest not just that minority ethnic organizations tend to serve as ethnic enclaves for minority students, but also that-consistent with the expectations of Hypothesis 1 -sororities and fraternities tend to serve as ethnic enclaves for White students.

\section{Variable Intercorrelations}

To get a flavor of the manner in which the attitude and organizational membership variables are related to one another, we present their correlations among White and minority students during the freshman wave in Table 3.

It is worth noting that the data in Table 3 support the idea that this university context is one in which ethnic identity is related to various forms of intergroup bias and other intergroup attitudes among both Whites and minorities. For example, Table 3 shows that the degree of ethnic identity was positively related not only to intergroup bias among both Whites and minorities (i.e., $r=.18$, $p<.01, r=.23, p<.01$, respectively), but also to factors such as miscegenation opposition, the sense of ethnic victimization, and the conviction that ethnic groups are locked into zero-sum conflict with each other.

\section{Determinants of Organizational Membership}

Past research has shown that, for minorities, the decision to join a minority ethnic organization in college is strongly related to

\footnotetext{
${ }^{4}$ For the precollege wave, these questions were framed as "will experience" discrimination instead of "experience" discrimination and "won't have" instead of "don't have."

${ }^{5}$ This question was first asked during the second wave.
} 


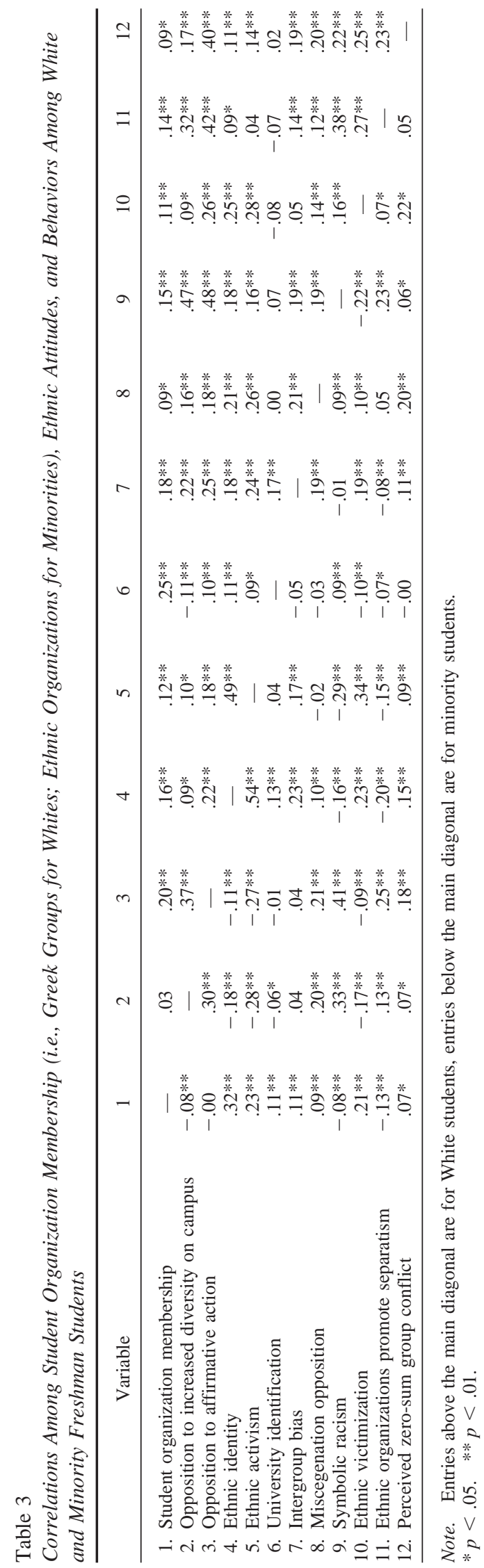

intergroup attitudes and to the degree of one's ethnic identity (Hurtado et al., 1999; Padilla, Trevino, Trevino, \& Gonzalez, 1997). After we confirmed the connection between intergroup attitudes and/or ethnic identity and the decision to join ethnic organizations among minorities, we tested our hypothesis that the decision to join a sorority or fraternity is driven by issues of ethnic and/or racial identity for White students.

\section{Ethnic Organization Membership for Minorities}

We explored the decision to join minority ethnic organizations in college as a function of the 11 scales that made up the four clusters of intergroup attitudes (e.g., racial policy attitudes, social identity attitudes) assessed during the first wave, just prior to the beginning of students' freshman year.

In the first substantive set of analyses, we used a series of logistic regression analyses to predict whether students were members of a minority ethnic organization between their freshman and senior years in college (scored 1 for membership, 0 for nonmembership) on the basis of the 11 precollege intergroup attitudes measured. These analyses were essentially bivariate, but they also controlled for student ethnicity (by the use of two dummy ethnicity vectors in which Asians served as the contrast group), gender, and social class ${ }^{6}$. Additionally, one overall multivariate logistic regression analysis was performed in which all 11 of the precollege attitudes were simultaneously included in the regression analysis, in addition to the controls for the two ethnicity dummy variables, gender and social class. The results of these analyses are found in Table 4.

Starting with the bivariate analyses in Table 4 , we see that 4 of the 11 variables were significantly related to the minority students' decision to join a minority ethnic organization. Not surprisingly, the strongest of these variables was the strength of the students' ethnic identities. The $\operatorname{Exp}(B)$ statistic gives odds ratio information and indicates that the odds of joining an ethnic student organization increased by a factor of 1.40 (i.e., a $40 \%$ increase) for every unit increase in the students' precollege ethnic identity $(p<.01)$. The bivariate analyses also showed that the odds of joining an ethnic organization grew with increasing precollege ethnic activism (i.e., $\operatorname{Exp}[B]=1.15, p<.01$ ), and one's degree of intergroup bias (i.e., $\operatorname{Exp}[B]=1.13, p<.05$ ).

However, it is also noteworthy that these bivariate analyses provided some evidence in support of the general ethnic pluralist argument. This is to say that, for minorities, joining a minority ethnic organization in college was related not only to the degree of one's ethnic identity and intergroup bias but also to the degree that one identifies with the larger, superordinate institution of the university. Thus, the more the students thought of themselves as UCLA students, the more likely they were to join a minority ethnically oriented student organization (i.e., $\operatorname{Exp}[B]=1.12, p<$ $.05)$.

When all 11 of the predictor variables were entered into the logistic regression equation simultaneously, only the degree of

\footnotetext{
${ }^{6}$ Social class was operationalized by asking the respondents to classify themselves in one of seven socioeconomic categories. These categories were (a) poor, (b) working class, (c) lower middle class, (d) middle class, (e) upper middle class, (f) lower upper class, and (g) upper class.
} 
Table 4

Membership in Minority Ethnic Organizations Among Minority Students as a Function of Precollege Attitudes

\begin{tabular}{|c|c|c|c|c|}
\hline \multirow[b]{2}{*}{ Independent variable in precollege year } & \multicolumn{2}{|c|}{ Ethnic organization } & \multirow[b]{2}{*}{$\begin{array}{c}\text { Bivariate LR } \\
\operatorname{Exp}(B) \text {-OR }\end{array}$} & \multirow[b]{2}{*}{$\begin{array}{c}\text { Multivariate LR } \\
\operatorname{Exp}(B)-\mathrm{OR}\end{array}$} \\
\hline & $\begin{array}{c}\text { Member } \\
M\end{array}$ & $\begin{array}{c}\text { Nonmember } \\
M\end{array}$ & & \\
\hline \multicolumn{5}{|l|}{ Social policy } \\
\hline Opposition to increased diversity on campus & 2.74 & 2.91 & 0.92 & 0.92 \\
\hline Opposition to affirmative action & 3.78 & 3.74 & 0.96 & 1.00 \\
\hline \multicolumn{5}{|l|}{ Social identity } \\
\hline Ethnic identity & 5.64 & 5.04 & $1.40 * *$ & $1.42 * *$ \\
\hline Ethnic activism & 3.74 & 3.44 & $1.15 * *$ & 1.00 \\
\hline University identification & 4.97 & 4.82 & $1.12 *$ & 1.02 \\
\hline \multicolumn{5}{|l|}{ Ethnic prejudice } \\
\hline Intergroup bias & 0.80 & 0.61 & $1.13 *$ & 1.00 \\
\hline Miscegenation opposition & 1.81 & 1.83 & 0.98 & 0.95 \\
\hline Symbolic racism & 3.84 & 3.82 & 1.01 & 1.05 \\
\hline \multicolumn{5}{|l|}{ Perceived group conflict } \\
\hline Ethnic victimization & 3.85 & 3.81 & 1.00 & 1.00 \\
\hline Ethnic organizations promote separatism & 2.86 & 3.05 & 0.92 & 0.95 \\
\hline Perceived zero-sum group conflict & 3.16 & 3.11 & 1.02 & 1.02 \\
\hline
\end{tabular}

Note. Bivariate and multivariate analyses include controls for gender, social class, and ethnicity. LR = logistic regression; $\mathrm{OR}=$ odds ratio.

$* p<.05$. ** $p<.01$.

one's ethnic identity was found to have a significant effect on the likelihood of joining an ethnic organization, net of the other variables and the demographic controls (i.e., $\operatorname{Exp}[B]=1.42, p<$ $.01)$. These results thus support the findings of previous research.

\section{Greek Group Membership for Whites}

The fact that ethnic identity was found to be the most important factor relating to the decision to join a minority ethnic organization among minorities seems intuitive and is consistent with previous research. In contrast, the role of ethnic identity and intergroup attitudes in White students' decisions to join a sorority or fraternity is much less obvious. For reasons explored in the introduction, our second hypothesis argues that various aspects of racial and/or ethnic identity are associated with the decisions of White students to join Greek organizations.

To explore this question, we repeated the type of analyses performed for the minority students above. This is to say, we explored a series of bivariate logistic regression analyses and one multivariate logistic regression analysis in which membership in a Greek organization during college (i.e., freshman through senior years, and while controlling for gender and social class) was predicted as a function of the White students' precollege ethnic and racial attitudes (see Table 5).

The results of the bivariate logistic regression analyses revealed that 4 of the 11 precollege attitudes were significantly related to the White students' likelihood of joining a Greek organization. As with the minority students, among Whites the likelihood of joining a sorority or fraternity was positively associated with identification as a university student (i.e., $\operatorname{Exp}[B]=1.20, p<.01$ ). More on point, and consistent with Hypothesis 3, the degree of White ethnic identity was indeed positively associated with the likelihood of joining a Greek organization. For every unit increase in the degree of White ethnic identity, the odds of joining a fraternity or sorority increased by $22 \%(p<.01)$. Also similar to the results found for minority students, among Whites, the decision to join a Greek organization was positively associated with one's degree of intergroup bias (i.e., $\operatorname{Exp}[B]=1.39, p<.01$ ).

However, in contrast to the findings for the minority students, among White students the decision to join Greek organizations was also related to one of the racial policy attitudes. Specifically, among Whites, the decision to go Greek in college was positively associated with precollege opposition to affirmative action (i.e., $\operatorname{Exp}[B]=1.19, p<.01$; see Table 5). This latter finding indicates that for every unit increase in White students' precollege opposition to affirmative action, the odds of their joining a sorority/ fraternity increased by $19 \%$.

Turning to the multivariate logistic regression analyses, we see that only 2 of the 11 precollege variables were able to make net contributions to the likelihood of White students joining a Greek organization, namely, precollege intergroup bias and the degree of ethnic identity (i.e., $\operatorname{Exp}[B]=1.23, p<.05, \operatorname{Exp}[B]=1.19, p<$ .05 , respectively). Thus, net of other factors, whereas the decision to join ethnic organizations was largely restricted to attitudes concerning the in-group and issues of ethnic identity among minorities, the decision to join Greek organizations among Whites was related not only to identification with the in-group but also to intergroup bias as well.

\section{Effects of Student Organizations on Intergroup Attitudes}

Although the data thus far seem to suggest that ethnic identity is an important factor in deciding to join a minority ethnic organization for minorities and that both ethnic identity and intergroup bias are implicated in the decision to join a Greek organization for Whites, it is not clear whether membership in these student organizations has any net effects on the ethnic and racial attitudes of 
Table 5

Membership in Greek Organizations Among White Students as a Function of Precollege Attitudes

\begin{tabular}{|c|c|c|c|c|}
\hline \multirow[b]{2}{*}{ Independent variable in precollege year } & \multicolumn{2}{|c|}{ Greek } & \multirow[b]{2}{*}{$\begin{array}{c}\text { Bivariate LR } \\
\operatorname{Exp}(B) \text {-OR }\end{array}$} & \multirow[b]{2}{*}{$\begin{array}{l}\text { Multivariate LR } \\
\operatorname{Exp}(B) \text {-OR }\end{array}$} \\
\hline & $\begin{array}{c}\text { Member } \\
M\end{array}$ & $\begin{array}{c}\text { Nonmember } \\
M\end{array}$ & & \\
\hline \multicolumn{5}{|l|}{ Social policy } \\
\hline Opposition to increased diversity on campus & 3.22 & 3.22 & 1.04 & 0.98 \\
\hline Opposition to affirmative action & 4.66 & 4.29 & $1.19 * *$ & 1.11 \\
\hline \multicolumn{5}{|l|}{ Social identity } \\
\hline Ethnic identity & 3.98 & 3.58 & $1.22 * *$ & $1.19 *$ \\
\hline Ethnic activism & 2.17 & 2.03 & 1.07 & 0.96 \\
\hline University identification & 5.13 & 4.88 & $1.20 * *$ & 1.14 \\
\hline \multicolumn{5}{|l|}{ Ethnic prejudice } \\
\hline Intergroup bias & 0.60 & 0.28 & $1.39 * *$ & $1.23^{*}$ \\
\hline Miscegenation opposition & 1.83 & 1.65 & 1.10 & 1.00 \\
\hline Symbolic racism & 3.97 & 3.82 & 1.15 & 1.00 \\
\hline \multicolumn{5}{|l|}{ Perceived group conflict } \\
\hline Ethnic victimization & 2.82 & 2.82 & 1.00 & 1.04 \\
\hline Ethnic organizations promote separatism & 3.74 & 3.63 & 1.03 & 0.99 \\
\hline Perceived zero-sum group conflict & 3.21 & 2.99 & 1.08 & 1.00 \\
\hline
\end{tabular}

Note. Bivariate and multivariate analyses include controls for gender and social class. LR $=$ logistic regression; $\mathrm{OR}=$ odds ratio

$* p<.05 . \quad * * p<.01$.

students at the end of their college years. It is to this central question that we now turn.

In attempting to answer this question, our general analytic strategy was to use multiple regression analysis to examine the students' ethnic attitudes at the end of their senior year in college as a function of membership in student organizations between their freshman and junior years in college, while controlling for gender, social class, and similar attitudes at baseline (i.e., during precollege summer orientation).

For example, in examining the effect of membership in a minority ethnic organization on minority students' attitudes toward affirmative action, the students' affirmative action attitude at the end of their senior year was regressed on (a) their baseline, precollege affirmative action attitude, (b) demographic factors (e.g., gender and class), and (c) whether they belonged to a minority ethnic student organization at any point between their freshman and junior years. Thus, the purpose of these analyses was to ascertain whether group membership in student organizations had any effect on students' attitudes, net of their precollege, baseline attitudes.

\section{Effects of Minority Ethnic Organizations on Minority Students}

The entries in Table 6 display the standardized beta coefficients for the senior year dependent variables regressed on the following: (a) prefreshman, baseline values (shown in the second column) and (b) whether the minority student was a member of an ethnic organization between the freshman and junior years in college (shown in the third column; scored 1 for membership, 0 for nonmembership). ${ }^{7}$ The coefficient of multiple determinance for the entire equation is shown in the last column.

Inspection of Table 6 shows that, for minority students, membership in minority ethnic organizations had significant effects on slightly less than half (5 of the 12) of the dependent variables at the end of the senior year. In order of strength of magnitude, these significant effects included: (a) an increased sense of ethnic victimization $(\beta=.13, p<.01)$, (b) increased ethnic identity $(\beta=$ $.13, p<.01)$, (c) increased ethnic activism $(\beta=.10, p<.01),(\mathrm{d})$ a decreased belief that ethnic organizations promote separatism on campus $(\beta=-.10, p<.05)$, and (e) increased perception of zero-sum conflict between ethnic groups $(\beta=.09, p<.05)$.

Thus, whereas a sense of ethnic victimization and a perception of zero-sum group conflict do not appear to be among the motives for joining minority ethnic organizations for minority students (see Table 4), they do appear to be among the results of membership in such organizations (see Table 6). Furthermore, the basic pattern of these effects did not dramatically change when we examined the data for each minority group separately (i.e., Asians, Latinos, and Blacks). Finally, these results are noteworthy for what they do not show. Namely, despite the fact that membership in ethnic organizations increases minority students' levels of social identity, sense of victimization, and even perceived group conflict, this membership does not seem to increase the students' intergroup bias. This latter finding is not consistent with the expectations derived from social identity theory (see Tajfel \& Turner, 1986).

\section{Effects of Sorority or Fraternity Membership on White Students}

We next examined the effects of membership in sororities and fraternities on the intergroup attitudes of White students using the same analytic strategy as was used with the minority students (see Table 7).

\footnotetext{
${ }^{7}$ These analyses also controlled for the ethnicity of the students, using dummy-variable coding, as well as the factors of gender and social class.
} 
Table 6

Ethnic Attitudes and Behavior Variables in Senior Year as Function of Prior Attitude Levels and Membership in Ethnic Organizations Among Minority Students

\begin{tabular}{|c|c|c|c|}
\hline Dependent variable in senior year & $\begin{array}{l}\text { Same attitude } \\
\text { (precollege), } \beta\end{array}$ & $\begin{array}{l}\text { Ethnic organization membership } \\
\quad \text { (freshman-junior years), } \beta\end{array}$ & $\begin{array}{c}\text { Model } \\
R^{2}\end{array}$ \\
\hline \multicolumn{4}{|l|}{ Social policy } \\
\hline Opposition to increased diversity on campus & $.25 * *$ & -.04 & $.17 * *$ \\
\hline Opposition to affirmative action & $.31 * *$ & -.06 & $.26 * *$ \\
\hline \multicolumn{4}{|l|}{ Social identity } \\
\hline Ethnic identity & $.47 * *$ & $.13 * *$ & $.29 * *$ \\
\hline Ethnic activism & $.35^{* *}$ & $.10^{* *}$ & $.28 * *$ \\
\hline Common in-group identity ${ }^{a}$ & $.38 * *$ & -.05 & $.14 * *$ \\
\hline University identification & $.18 * *$ & .03 & $.05 * *$ \\
\hline \multicolumn{4}{|l|}{ Ethnic prejudice } \\
\hline Intergroup bias & $.34 * *$ & .03 & $.13 * *$ \\
\hline Miscegenation opposition & $.35^{* *}$ & .03 & $.16 * *$ \\
\hline Symbolic racism & $.36 * *$ & -.05 & $.23 * *$ \\
\hline \multicolumn{4}{|l|}{ Perceived group conflict } \\
\hline Ethnic victimization & $.30 * *$ & $.13^{* *}$ & $.18 * *$ \\
\hline Ethnic organizations promote separatism & $.21 * *$ & $-.10^{*}$ & $.09 * *$ \\
\hline Perceived zero-sum group conflict & $.25^{* *}$ & $.09 *$ & $.08 * *$ \\
\hline
\end{tabular}

a This variable was first measured during the freshman year, and therefore, the freshman year is used as the control variable, and membership in ethnic organizations between sophomore and junior years is used as the independent variable.

$* p<.05 . \quad * * p<.01$.

As can be seen in Table 7, among White students, membership in sororities and fraternities also appeared to affect a broad array of intergroup attitudes after controlling for the baseline attitudes and demographic factors (i.e., gender and social class). Net of the prefreshman attitudes and in order of the effect sizes, membership in Greek organizations (a) increased the sense that ethnic organizations cause ethnic tension on campus $(\beta=.19, p<.01)$, (b) increased the sense of ethnic victimization $(\beta=.18, p<.01)$, (c) increased the level of symbolic racism $(\beta=.17, p<.01)$, (d) increased opposition to interracial dating and marriage $(\beta=.15$, $p<.01$ ), (e) led to greater opposition to ethnic diversity on campus $(\beta=.14, p<.05)$, and (f) marginally increased the level of intergroup bias $(\beta=.09, p<.06)^{8}$. It is also interesting to note that whereas membership in Greek organizations seemed to increase various forms of interethnic bias and social distance to ethnic others, membership in these organizations also increased the students' identification with the university as an institution $(\beta=$ $.13, p<.05)$.

Thus, among White students, membership in Greek organizations appears to both be affected by and to affect racial policy preferences, social identity, and ethnic prejudice. Although a sense of ethnic victimization, opposition to intergroup dating and marriage, and symbolic racism do not appear to be among the motives that White students have for joining Greek organizations (see Table 5), they do appear to be among the consequences of membership in such organizations (see Table 7). The effects of organizational membership among White students are quite consistent with social identity theory. Membership in Greek organizations did increase various indices of perceived group conflict, ethnic victimization, and ethnic prejudice. However, for this theory to be more strongly confirmed, we must also show that ethnic identity actually mediates the relationship between organizational membership and various forms of prejudice and intergroup bias. It is to this last question that we now turn.

\section{Mediational Effects of Ethnic Identity}

Further following the logic of social identity theory, we explore the degree to which increased levels of ethnic identity mediated the effects of organizational membership on intergroup attitudes. We began these mediational analyses by exploring opposition to increased diversity on campus. Thus, we were interested in whether membership in these student organizations increases the degree of one's ethnic identity, which in turn leads to increased diversity opposition. We repeated these analyses for the other intergroup attitudes as well. In all cases, the significance of the mediation was assessed by the use of $t$ tests for mediation found in the LISREL 8 (Jöreskog \& Sörbom) program. ${ }^{9}$

\section{Mediational Effects of Ethnic Identity Among Minority Students}

These analyses exploited all five waves of the panel data and used the baseline measures of ethnic identity and opposition to increased diversity as controls. Membership in a minority ethnic organization during the freshman and sophomore years defined the primary independent variable of interest, ethnic identity at the end of junior year functioned as a mediator, and diversity opposition at

\footnotetext{
${ }^{8}$ In addition, Greek organizational membership among Whites tended to both marginally increase the positive affect toward Whites and marginally decrease the positive affect toward minorities.

${ }^{9}$ These mediational tests in LISREL are essentially equivalent to the common Sobel's procedure used in connection with least squares regression (see, e.g., Kaplan, 2000, pp. 35-36). That is to say that this LISREL test assesses whether and the degree to which the total effect of organizational membership during the freshman to sophomore years was significantly reduced once the mediational effect of ethnic identity in the junior year was considered.
} 
Table 7

Ethnic Attitudes and Behavior Variables in Senior Year as Function of Prior Attitude Levels and Membership in Greek Organizations Among White Students

\begin{tabular}{|c|c|c|c|}
\hline Dependent variable in senior year & $\begin{array}{l}\text { Same attitude } \\
\text { (precollege), } \beta\end{array}$ & $\begin{array}{c}\text { Greek membership } \\
\text { (freshman-junior years), } \beta\end{array}$ & $\begin{array}{c}\text { Model } \\
R^{2}\end{array}$ \\
\hline \multicolumn{4}{|l|}{ Social policy } \\
\hline Opposition to increased diversity on campus & $.39 * *$ & $.14 *$ & $.25 * *$ \\
\hline Opposition to affirmative action & $.47 * *$ & .08 & $.25 * *$ \\
\hline \multicolumn{4}{|l|}{ Social identity } \\
\hline Ethnic identity & $.40 * *$ & .04 & $.19 * *$ \\
\hline Ethnic activism & $.47 * *$ & .08 & $.23 * *$ \\
\hline Common in-group identity ${ }^{\mathrm{a}}$ & $.30 * *$ & -.10 & $.11 * *$ \\
\hline University identification & $.14^{* *}$ & $.13 *$ & $.06 * *$ \\
\hline \multicolumn{4}{|l|}{ Ethnic prejudice } \\
\hline Intergroup bias & $.24 * *$ & .09 & $.08 * *$ \\
\hline Miscegenation opposition & $.23 * *$ & $.15^{* *}$ & $.09 * *$ \\
\hline Symbolic racism & $.43 * *$ & $.17 * *$ & $.28 * *$ \\
\hline \multicolumn{4}{|l|}{ Perceived group conflict } \\
\hline Ethnic victimization & $.27 * *$ & $.18 * *$ & $.11 * *$ \\
\hline Ethnic organizations promote separatism & $.22 * *$ & $.19 * *$ & $.10 * *$ \\
\hline Perceived zero-sum group conflict & $.30 * *$ & .06 & $.10 * *$ \\
\hline
\end{tabular}

a This variable was first measured during the freshman year, and therefore, the freshman year is used as the control variable, and membership in Greek organizations between sophomore and junior years is used as the independent variable.

$* p<.05$. ** $p<.01$.

the end of the senior year served as the ultimate outcome variable. ${ }^{10}$ Product-moment correlations served as the input data for all the LISREL analyses. The results of this analysis showed a very significant mediated effect of ethnic identity on ethnic activism during the senior year (indirect effect $=.03, t=2.46$; $p<.01$; see Table 8).

The results for the other intergroup attitudes showed that for minority students, ethnic identity had a small yet statistically reliable mediational role for 3 of the remaining 10 dependent variables. Thus, the mediational tests showed that ethnic identity mediated the relationship between membership in an ethnic organization and (a) identification with the university group (indirect effect $=.02, t=2.08, p<.05$ ); (b) intergroup bias (indirect effect $=.02, t=2.21, p<.05$ ); and (c) perceived zero-sum group conflict (indirect effect $=.02, t=2.10, p<.05$ ).

\section{Mediational Effects of Ethnic Identity Among White Students}

We used the same analytic strategy as used for the minority students to examine the mediational effects of ethnic identity on the dependent variables among White students. Significant mediated relationships were found for 6 of the 11 cases. The results of these LISREL mediation analyses showed that there was a small, yet statistically significant, indirect or mediated effect of Greek membership with respect to (a) opposition to affirmative action (indirect effect $=.04, t=1.93, p<.05$ ); (b) ethnic activism (indirect effect $=.08, t=3.16, p<.01$ ); (c) miscegenation opposition (indirect effect $=.07, t=2.67, p<.01$ ); (d) symbolic racism (indirect effect $=.05, t=2.49, p<.01$ ); (e) sense of ethnic victimization (indirect effect $=.05, t=2.16, p<.05$ ); and (f) feeling that ethnic organizations promote ethnic separatism (indirect effect $=.03, t=1.83, p<.05$; see Table 8).
Thus, consistent with the expectations of social identity theory, these results indicated that for both minority and White students, the effects of membership in ethnically oriented student organizations on intergroup attitudes were, at least partially, mediated by ethnic identification.

\section{DISCUSSION}

Using the multicultural and social identity perspectives, this study explored the intergroup antecedents and consequences of membership in ethnic college organizations among minority students and in Greek organizations among White students. Those using a multicultural framework have long argued that, rather than increasing ethnic tension and isolation on campus, involvement in ethnically oriented student organizations among minority students generally is driven by a desire to engage in broader university life and also serves as a conduit for involvement in the broader activities of the university environment. In contrast, the logic of social identity theory suggests that, to the extent that such organizational membership stimulates the ethnic identities of minority students, it is more likely to increase ethnic segregation and the tendency toward ethnocentric bias. Importantly, however, and in contrast to the emphasis on minority organizations in the discourse in the multicultural perspective, we argue that fraternities and sororities have similar effects for White students as ethnic minority organizations have for minority students.

\footnotetext{
${ }^{10}$ Before being submitted to the mediational analyses, these were first controlled for the effects of gender; social class; and, in the case of the minorities, for the ethnic group differences between Asians, Blacks, and Latinos. Thus the data were residuals, after the effects of the covariates had been removed.
} 
Table 8

The Indirect Effects Between Ethnic Identity During the Junior Year and Intergroup Attitudes During the Senior Year for Minority and White Students

\begin{tabular}{|c|c|c|c|c|}
\hline \multirow[b]{2}{*}{ Dependent variable in senior year } & \multicolumn{2}{|c|}{ Minority } & \multicolumn{2}{|c|}{ White } \\
\hline & $\begin{array}{c}\text { Indirect } \\
\text { effect size }\end{array}$ & $\begin{array}{l}\text { Indirect } \\
\text { effect } t\end{array}$ & $\begin{array}{c}\text { Indirect } \\
\text { effect size }\end{array}$ & $\begin{array}{l}\text { Indirect } \\
\text { effect } t\end{array}$ \\
\hline \multicolumn{5}{|l|}{ Social policy } \\
\hline Opposition to increased diversity on campus & -.01 & -1.77 & .03 & 1.49 \\
\hline Opposition to affirmative action & -.00 & $<1$ & .04 & $1.93 *$ \\
\hline \multicolumn{5}{|l|}{ Social identity } \\
\hline Ethnic activism & .03 & $2.46^{* *}$ & .08 & $3.16^{* *}$ \\
\hline Common in-group identity ${ }^{a}$ & .00 & $<1$ & .00 & $<1$ \\
\hline University identification & .02 & $2.08 *$ & .02 & 1.29 \\
\hline \multicolumn{5}{|l|}{ Ethnic prejudice } \\
\hline Intergroup bias & .02 & $2.21 *$ & .02 & 1.50 \\
\hline Miscegenation opposition & .01 & 1.64 & .07 & $2.67 * *$ \\
\hline Symbolic racism & .00 & $<1$ & .05 & $2.49 * *$ \\
\hline \multicolumn{5}{|l|}{ Perceived group conflict } \\
\hline Ethnic victimization & .02 & 1.64 & .05 & $2.16^{*}$ \\
\hline Ethnic organizations promote separatism & -.01 & -1.54 & .03 & $1.83^{*}$ \\
\hline Perceived zero-sum group conflict & .02 & $2.10 *$ & .03 & 1.22 \\
\hline
\end{tabular}

For the most part, the results of our analyses among minority students were largely consistent with social identity theory rather than the multicultural perspective. In agreement with the multicultural arguments and previous empirical findings (e.g., Ethier \& Deaux, 1994; Hurtado et al., 1994; Hurtado et al., 1999; Moran et al., 1994; Reyes, 1997; Rooney, 1985; Treviño, 1992), our results did indeed show that the decision to join ethnically oriented student organizations among minority students was associated with high levels of ethnic identification and ethnic activism, as well as with the sense of being a part of the larger university community. Also in line with previous research within the multicultural tradition, we found that membership in such organizations among minority students further increased the level of their ethnic identity and the desire to be politically active on behalf of the ethnic group.

On the other hand, and in direct contrast to previous research within the multiculturalist tradition, although the decision to join ethnic organizations was associated with a positive sense of belonging to the larger university, there was no indication that the experiences in these ethnically oriented student organizations increased the students' sense of common identity with members of other groups or their sense of belonging to the wider university community. Furthermore, and in line with critics of multiculturalism (e.g., Chavez, 1982; D'Souza, 1991), among minority students the evidence suggested that membership in ethnically oriented student organizations actually increased the perception that ethnic groups are locked into zero-sum competition with one another and the feeling of victimization by virtue of one's ethnicity. In general, these results for attitudes and perceptions among minority students appeared to be much more consistent with the expectations of social identity theory than with the expectations of the multicultural perspective.
Also consistent with the expectations of social identity theory was the finding concerning the mediated effect of ethnic identity for minority students. This is to say that, all else being equal, membership in ethnic organizations among minorities increased the students' sense of ethnic identity, which in turn increased their sense of zero-sum competition among ethnic groups. These very last findings deviate slightly from the results found by Ethier and Deaux (1994), who examined a small sample $(N=36)^{11}$ of Latino students at two Ivy League campuses. Although Ethier and Deaux (1994) did find that involvement in ethnic activities on campus was positively associated with the degree of one's ethnic identity before college, they did not find that ethnic involvement increased identity threat once the students were on campus. However, their measure of identity threat differed from our dependent measures. Specifically, they assessed perceptions of identity threat by such items as "I cannot talk to my friends at school about my family or my culture." In contrast, our dependent variable most similar to this threat index assessed what we called "ethnic victimization," defined as the perception that the self and other members of one's ethnic group are targets of ethnic discrimination. It is clear that these are not exactly the same constructs. Only additional replications will be able to unfurl the possible factors responsible for the differences in results (e.g., difference in the sample size, the degree of ethnic heterogeneity of the campus, geographical location of the campus). Using social identity theory, we have also reasoned that the conflict-inducing effects of membership in ethnically oriented

\footnotetext{
${ }^{11}$ Out of an initial sample of 45 students who participated in the first wave of the Ethier and Deaux (1994) three-wave panel study, 36 students participated in all three waves.
} 
student organizations should not just be restricted to minority students but should be found with respect to White students as well. Given the exclusionary history of fraternities and sororities on the American campus, we strongly suspected that these Greek organizations would tend to function as "ethnic clubs" for White students. The data provided consistent evidence of the exclusionary and ethnic nature of Greek groups. First, White students were found to be strongly and significantly overrepresented in these organizations, whereas minority students were strongly and significantly underrepresented in these groups. Second, and also consistent with expectations, when we restricted analysis to White students, it was found that the probability of joining a Greek organization in college was significantly related to precollege levels of White ethnic identity. However, in contrast to the findings among minority students, among whom the decision to join ethnically oriented student organizations was largely restricted to attitudes toward the in-group and in-group identification, among White students the decision to join Greek organizations showed a greater net association with attitudes toward out-groups, specifically intergroup bias with respect to generalized "others." Not only was the decision to join a Greek organization related to various precollege indices of ethnic identity and intergroup bias, but membership in these organizations also appeared to have broad effects on the ethnic and racial attitudes of White students. Although membership in Greek organizations did increase White students' identification with the university as an institution, it also increased their opposition to an ethnically diverse campus, their belief that ethnic organizations promote separatism, their opposition to interracial marriage and dating, their symbolic racism, and their sense of ethnic victimization. In other words, among Whites, membership in fraternities and sororities appeared to produce even more ethnocentric, conflict-inducing, and exclusionary effects than membership in ethnic student organizations produced among minority students. Furthermore, as with minority students, and consistent with the expectations of social identity theory, at least a portion of these conflict-inducing effects among White students were mediated by White ethnic identity. That is, membership in Greek groups increased the degree of members' ethnic and/or racial identity, which in turn increased the White students' opposition to affirmative action, ethnic group activism, miscegenation opposition, symbolic racism, and sense that they were being victimized by virtue of their ethnic group membership.

Perhaps one of the most troubling findings of this study is that ethnically oriented student organization membership appeared to increase the sense of ethnic victimization among both White and minority students. Although the sense of group victimization has been a relatively understudied construct among contemporary social psychologists, there is strong ethnographic evidence that this is a particularly important and central variable implicated in several intense and bloody intergroup conflicts around the world, including Bosnia, Cypress, Kosovo, the Crimea, the Middle East, Northern Ireland, Rwanda, and the Sudan. The sense of group victimization has shown itself to be easily mobilizable, often with devastating effect when mobilized on behalf of relatively powerful groups (see, e.g., Abdulganiyev, 2002; de Figueiredo \& Weingast, 1997; Foley, 1999; Ivie, 2002; Mertus, 2001; Murithi, 1998; Ozcelik, 2000; Richardson \& Sen, 1996; Subotić, 2000).
On the other hand, although the findings that membership in a minority ethnic organization increases minority students' perceptions of ethnic victimization appear to be somewhat troubling, other research we have conducted using data from these students (not reported here) shows that such perceptions of victimization also appear to have important benefits for these students (Van Laar \& Levin, 2002). Specifically, controlling for earlier differences in actual abilities or skills among students, when Black students make more attributions to discrimination in college, they also perform better academically and obtain higher grade point averages (see also Levin \& Van Laar, 2002). Thus, although possibly increasing ethnic tension on campus, the laying of blame more externally through perceptions of higher perceived levels of ethnic victimization may have important positive payoffs for minority achievement in college.

Although our results are somewhat at odds with the limited research on the effects of ethnic organizations among minority students, our results are clearly in line with the body of literature concerning the effects of Greek organizations among White students and the thrust of empirical results generated by social identity theory. Despite a few exceptions (e.g., Lottes \& Kuriloff, 1994; Wilder et al., 1986), congruent with our own results, the available literature tends to show that sororities and fraternities foster somewhat xenophobic, authoritarian, and prejudiced attitudes and values among White students (see also Bohrnstedt, 1969; Longino \& Kart, 1973; Martin \& Hummer, 1989; Muir, 1991; Wilder et al., 1978). Furthermore, whereas there has been a tendency to associate ethnically oriented student clubs with ethnic minorities, our results suggest that some of the most powerful ethnic enclaves come in the form of sororities and fraternities that in part function as ethnic clubs for White students_clubs having broad and pervasive effects on intergroup attitudes. Thus, even on campuses as ethnically heterogeneous as UCLA in the late 1990s, and despite the nondiscriminatory flavor of their membership clauses, Greek organizations still seem to have the same exclusionary overtones that characterized them during all of the 19th century and most of the 20th century. Even more interesting, at least at this major California university, our results seem to suggest that these student organizations now also appear to be nurseries for the sense of White victimization.

However, we must qualify our conclusions somewhat by recognizing the fact that it is possible that the discriminatory effects of the Greek system on the UCLA campus were so strong because of this school's relatively high degree of ethnic heterogeneity. Universities at which these trends have not been found appear to be substantially more ethnically homogeneous (see, e.g., Lottes \& Kuriloff, 1994). This suggests that one of the questions remaining to be answered is whether the effects of Greek and other ethnic organizations might vary as a function of the ethnic heterogeneity on campus or as a function of other campus characteristics (e.g., academic selectivity). There is also some recent evidence that the sense of ethnic victimization among White students is not just restricted to members of Greek organizations. A recent multicampus study by Rothman, Lipset, and Nevitte (2003) shows that the sense of ethnic victimization among the White student body increases with increasing levels of Black enrollment at the university. In other words, rather than decreasing ethnic tension, multiethnic university environments appear to have the exact opposite effects for White students. Finally, even though we have found a 
certain degree of similarity in the antecedents and effects of ethnically oriented student organizations within this multiethnic context, this in no way implies that social ideologies and group construals will always have the same implications for members of dominant and subordinate groups. There is a good deal of recent research that has discussed the specific conditions and circumstances in which social ideologies and group construals have very different and even opposite implications for members of dominant and subordinate groups (see, e.g., Devine, Evett, \& Vasquez Suson, 1996; Dovidio, Gaertner, \& Kafati, 2000; Sidanius, Levin, Federico, \& Pratto, 2001). Rather, what is remarkable about these findings is the surprising level of similarity in the covariates and implications of organizational membership for White and minority students, given what is now known about the manner in which the implications of social ideologies and groups can differ for members of dominant and subordinate groups.

Altogether then, the effects of both minority and White ethnic organizations appear to be substantially more antagonistic and less benign than has been suggested in past research (e.g., Ethier \& Deaux, 1994; Hurtado et al., 1994; Hurtado et al., 1999; Moran et al., 1994; Reyes, 1997; Rooney, 1985; Treviño, 1992). We suggest that these contrasting conclusions are primarily because of the fact that we have used a much wider and more comprehensive range of intergroup measures than has been used in the past (e.g., sense of ethnic victimization) and have also examined the effects of ethnic organizations for both minority and White students. Although we agree with multiculturalists that ethnic organizations seem to offer minority students a sense of safety, a platform from which to engage in political activism, and even a springboard for increased levels of achievement (Levin \& Van Laar, 2002; Van Laar \& Levin, 2002; see also Hall \& Allen, 1989), consistent with the implications of social identity theory, it is also true that membership in these organizations has a tendency to increase perceptions of group victimization, intergroup bias, and perceived zero-sum conflict between groups.

\section{References}

Abdulganiyev, K. (2002). Institutional development of the Crimean Tatar National Movement. Retrieved July 15, 2003 from International Committee for Crimea Web site: http://www.iccrimea.org/ scholarly/national-movement.html

Bohrnstedt, G. W. (1969). Conservatism, authoritarianism and religiosity of fraternity pledges. Journal of College Student Personnel, 10, 36-43.

Broadway, R., \& Flesch, S. (2000, November). Question of integration versus segregation arises on Penn State McKeesport Campus. Penn State McKeesport Collegian. Retrieved July 15, 2003 from http:// psumkcollegian.tripod.com/stories/2000/November/campusnews/ question_of_intergration_or_segregation_arises_on_PSUMK_campus .htm

Chavez, E. (1982, August). Minority student involvement in student activities. Bulletin of the Association of College Unions-International, $15-16$.

Crisostomo, L. A. (2001, November 19). Neo-segregation occurring on campus. Retrieved July 15, 2003 from http://www.badgerherald.com/ vnews/display.v/ART/2001/11/19/3bf9cfbb438e2

De Figueiredo, R. J. P. Jr., \& Weingast, B. R. (1997). The rationality of fear: Political opportunism and ethnic conflict. Retrieved July 20, 2003 from http://www.ciaonet.org/conf/iwp01/iwp01ag. html

Devine, P. G., Evett, S. R., \& Vasquez Suson, K. A. (1996). Exploring the interpersonal dynamics of intergroup contact. In R. M. Sorrentino \&
E. T. Higgins (Eds.), Handbook of motivation and cognition: Vol. 3. The interpersonal context (pp. 423-464). New York: Guilford Press.

Dovidio, J. F., Gaertner, S. L., \& Kafati, G. (2000). Group identity and intergroup relations: The common in-group identity model. In S. R. Thye, E. J. Lawler, M. W. Macy, \& H. A. Walker (Eds.), Advances in group processes (Vol. 17, pp. 1-34). Stamford, CT: JAI Press.

D'Souza, D. (1991). Illiberal education: The politics of race and sex on campus. New York: Free Press.

Duckitt, J. (1989). Authoritarianism and group identification: A new view of an old construct. Political Psychology, 10, 63-84.

Ellemers, N., Van Knippenberg, A., De Vries, N., \& Wilke, H. (1988). Social identification and permeability of group boundaries. European Journal of Social Psychology, 18, 497-513.

Ellemers, N., Van Knippenberg, A., \& Wilke, H. A. (1990). The influence of permeability of group boundaries and stability of group status on strategies of individual mobility and social change. British Journal of Social Psychology, 29, 233-246.

Ethier, K. A., \& Deaux, K. (1994). Negotiating social identity when contexts change: Maintaining identification and responding to threat. Journal of Personality and Social Psychology, 67, 243-251.

Fay, P. J., \& Middleton, W. C. (1939). Certain factors related to liberal and conservative attitudes of college students, sex, classification, fraternity membership, major subject. Journal of Educational Psychology, 30, 378-390.

Foley, M. W. (1999, April 23-26). Memory, forgiveness and reconciliation: Confronting the violence of history. Report on a Conference at the Institute on Conflict Resolution and Ethnic Conflict (Incore). Retrieved April 7, 2004 from http://arts-sciences.cua.edu/pol/faculty/ conferenceRpt.htm

Gilliard, M. D. (1996). Racial climate and institutional support factors affecting success in predominantly White institutions: An examination of African American and White student experiences. Unpublished doctoral dissertation, University of Michigan.

Gist, N. (1955). Fraternal membership problems, policies and minority students: The case of Missouri University. Social Problems, January, 2, $165-172$.

Glisan, M. H. (1992). White students' racial attitudes and racial identity development in a liberal arts environment. Dissertation Abstracts International, 53(10), 3453A.

Hall, M. L., \& Allen, W. R. (1989). Race consciousness among African American college students. In G. L. Berry \& J. K. Asamen (Eds.), Black students: Psychological issues and academic achievement (pp. 172197). Newbury Park, CA: Sage.

Hendricks, M. L. (1996). Racial identity development of African-American male fraternity members and nonmembers at historically Black colleges and universities and predominantly White campuses. Dissertation $A b-$ stracts International, 58(3), 0752A.

Hinkle, S., \& Brown, R. (1990). Intergroup comparisons and social identity: Some links and lacunae. In D. Abrams \& M. A. Hogg (Eds.), Social identity theory: Constructive and critical advances (pp. 48-70). London: Harvester-Wheatsheaf.

Hughes, M. (1992). Overview. In M. C. Terrell (Ed.). Diversity, disunity, and campus community (pp. xii-xix, 199-223). Washington, DC: National Association of Student Personnel Administrators. (ERIC Document Reproduction Service No. ED356749).

Hurtado, S. (1990). Campus racial climates and educational outcomes. Unpublished doctoral dissertation, University of California, Los Angeles.

Hurtado, S. (1993, May). The institutional climate for diversity: The climate for talented Latino students. Paper presented at the annual forum of the Association for Institutional Research, Chicago.

Hurtado, S., Dey, E. L., \& Treviño, J. G. (1994, May-June). Exclusion or self-segregation? Interaction across racial/ethnic groups on college 
campuses. Paper presented at the American Education Research Association, New Orleans, LA.

Hurtado, S., Milem, J., Clayton-Pedersen, A., \& Allen, W. (1998). Enhancing campus climates for racial/ethnic diversity: Educational policy and practice. Review of Higher Education, 21, 279-302.

Hurtado, S., Milem, J., Clayton-Pedersen, A., \& Allen, W. (1999). Enacting diverse learning environments: Improving the climate for racial/ ethnic diversity in higher education. ASHE-ERIC Higher Education Report, 26, 8.

Ivie, R. L. (2002, April). Terrorism at democracy's frontier. Retrieved July 15, 2003 from http://www.indiana.edu/ ivieweb/frontier.htm

Jetten, J., Spears, R., \& Manstead, A. S. R. (1996). Intergroup norms and intergroup discrimination: Distinctive self-categorization and social identity effects. Journal of Personality and Social Psychology, 71, 1222-1233.

Jöreskog, K. G., \& Sörbom, D. (1993). LISREL 8 user's reference guide. Chicago: Scientific Software.

Kaplan, D. (2000). Structural equation modeling: Foundations and extensions. Thousands Oaks, CA: Sage.

Kelly, C. (1993). Group identification, intergroup perception and collective action. European Review of Social Psychology, 4, 59-83.

LeCount, D. W. (1987). American Indian students in college. In D. J. Wright (Ed.), Responding to the needs of today's minority students. New directions for student services (No. 38, pp. 65-79). San Francisco: Jossey-Bass.

Lee, A. M. (1955a). Can social fraternities be democratic? Journal of Higher Education, 26, 173-179.

Lee, A. M. (1955b). Fraternities without brotherhood: A study of prejudice on the American campus. Boston: Beacon Press.

Levin, S., \& Sidanius, J. (1999). Social dominance and social identity in the United States and Israel: Ingroup favoritism or outgroup derogation? Political Psychology, 20, 99-126.

Levin, S., Sidanius, J., Rabinowitz, J. L., \& Federico, C. (1998). Ethnic identity, legitimizing ideologies and social status: A matter of ideological asymmetry. Political Psychology, 19, 373-404.

Levin, S., \& Van Laar, C. (2002, June). Causes and consequences of ethnic segregation in college. Paper presented at the Biannual Meeting of the Society for the Psychological Study of Social Issues, Toronto, Ontario, Canada.

Longino, C. F., Jr., \& Kart, C. S. (1973). The college fraternity: An assessment of theory and research. Journal of College Student Personnel, 14, 118-125.

Lottes, I. L., \& Kuriloff, P. J. (1994). The impact of college experience on political and social attitudes. Sex Roles, 31, 31-54.

Martin, P. Y., \& Hummer, R. A. (1989). Fraternities and rape on campus. Gender and Society, 3, 457-473.

McDermott, K. (2002). Thesis raises troubling questions about race at Dartmouth. Retrieved July 15, 2003 from http://www.southend .wayne.edu/days/may2002/5302002/news/dartmouth/dartmouth.html

Mertus, J. (2001). The impact of intervention on local human rights culture. A Kosovo case study. The Global Review of Ethnopolitics, 1, 21-36.

Miller, L. D. (1973). Distinctive characteristics of fraternity members. Journal of College Student Personnel, 14, 126-128.

Mitchell, S. L., \& Dell, D. M. (1992). The relationship between Black students' racial identity attitude and participation in campus organizations. Journal of College Student Development, 33, 39-43.

Moran, J. J., Yengo, L., \& Algier, A. M. (1994). Participation in minorityoriented cocurricular organizations. Journal of College Student Development, 35, 143.

Muir, D. E. (1991). White fraternity and sorority attitudes towards Blacks on a deep-south campus. Sociological Spectrum, 11, 93-103.

Murithi, T. (1998). Electoral systems and the management of ethnic con- flict in Africa. Retrieved July 15, 2003 from http://www.psa.ac.uk/cps/ 1998/murithi.pdf

Ozcelik, S. (2000, March-April). Psychological, historical and political barriers between Greek and Turkish Cypriots. Retrieved July 15, 2003 from http://www.geocities.com/tatarkirim/kibris1.html

Padilla, R. V., Trevino, J., Trevino, J., \& Gonzalez, K. (1997). Developing local models of minority student success in college. Journal of College Student Development, 38, 125-135.

Pascarella, E. T., Edison, M., Nora, A., Hagedorn, L. S., \& Terenzini, P. T. (1996). Influences on students' openness to diversity and challenge in the first year of college. Journal of Higher Education, 67, 174-195.

Plant, W. T. (1958). Sex, intelligence and sorority or fraternity membership and changes in ethnocentrism over a two-year period. Journal of Genetic Psychology, 93, 53-57.

Raudenbush, S. W., \& Bryk, A. S. (2001). Hierarchical linear models: Applications and data analysis methods (2nd ed.). Thousand Oaks, CA: Sage.

Reicher, S. (in press). The context of social identity: Domination, resistance and change. Political Psychology.

Reyes, G. A. (1997). Does participation in an ethnic fraternity enable persistence in college? Dissertation Abstracts International, 58(11), 4207A.

Richardson, J. M., Jr., \& Sen, S. (1996). Ethnic conflict and economic development: A policy oriented analysis. Retrieved July 15, 2003 from School of International Service, American University Web site: http:// www.american.edu/jrich/Richardson.ethnic.confl.html

Rooney, G. D. (1985). Minority students' involvement in minority student organizations: An exploratory study. Journal of College Student Personnel, 26, 450-456.

Rothman, S., Lipset, S. M., \& Nevitte, N. (2003). Does enrollment diversity improve university education? International Journal of Public Opinion Research, 15, 8-26.

Scott, J. F. (1965). The role of the college sorority in endogamy. American Sociological Review, 30, 514-526.

Sears, D. O., Sidanius, J., \& Bobo, L. (2000). Racialized politics: Values, ideology, and prejudice in American public opinion. Chicago: University of Chicago Press.

Segal, B. E. (1965). Fraternities, social distance, anti-Semitism among Jewish and non-Jewish undergraduates. Sociology of Education, 38, 251-265.

Sidanius, J., Feshbach, S., Levin, S., \& Pratto, F. (1997). The interface between ethnic and national attachment: Ethnic pluralism or ethnic dominance? Public Opinion Quarterly, 61, 103-133.

Sidanius, J., Levin, S., Federico, C., \& Pratto, F. (2001). Legitimizing ideologies: The social dominance approach. In J. Jost \& B. Major (Eds.), The psychology of legitimacy: Emerging perspectives on ideology, justice, and intergroup relations (pp. 307-331). Cambridge, England: Cambridge University Press.

Sinclair, S., Sidanius, J., \& Levin, S. (1998). The interface between ethnic and social system attachment: The differential effects of hierarchyenhancing and hierarchy-attenuating environments. Journal of Social Issues, 54, 741-757.

Subotić, J. (2000). The role of intelligentsia and media in creating a national worldview: The case of Serbia. Retrieved July 15, 2003 from http://faculty.maxwell. syr.edu/jrshiffman/symposium\%20files/Best $\%$ 20Papers\%20(pdf)/Subotic\%20paper.pdf

Tajfel, H., \& Turner, J. C. (1986). The social identity theory of intergroup relations. In S. Worchel \& W. D. Austin (Eds.), The psychology of intergroup relations (pp. 7-24). Chicago: Nelson-Hall.

Treviño, J. G. (1992). Participation in ethnic/racial student organizations. Dissertation Abstracts International, 53(12), 4230A.

Turner, J. C. (1999). Some current issues in research on social identity and self-categorization theories. In N. Ellemers, R. Spears, \& B. Doosje 
(Eds.), Social identity: context, commitment, content (pp. 6-34). Malden, MA: Blackwell.

Van Laar, C., \& Levin, S. (2002, June). Minority achievement on the multicultural campus. Paper presented at the biannual meeting of the Society for the Psychological Study of Social Issues, Toronto, Ontario, Canada.

Wilder, D. H., Hoyt, A. E., Doren, D. M., Hauch, W. E., \& Zettle, R. D. (1978). The impact of fraternity and sorority membership on values and attitudes. Journal of College Student Personnel, 19, 445-449.

Wilder, D. H., Hoyt, A. E., Surbeck, B, S., Wilder, J. C., \& Carney, P. A.
(1986). Greek affiliation and attitude change in college students. Journal of College Student Personnel, 27, 510-519.

Yancey, A. K., Aneshensel, C. S., \& Driscoll, A. K. (2001). The assessment of ethnic identity in a diverse urban youth population. Journal of Black Psychology, 27, 190-208.

Received July 25, 2002 Revision received January 19, 2004

Accepted February 6, 2004

\section{American Psychological Association SubSCRIPTION Claims InFormation}

Today's Date:

We provide this form to assist members, institutions, and nonmember individuals with any subscription problems. With the appropriate information we can begin a resolution. If you use the services of an agent, please do NOT duplicate claims through them and directly to us. PLEASE PRINT CLEARLY AND IN INK IF POSSIBLE.

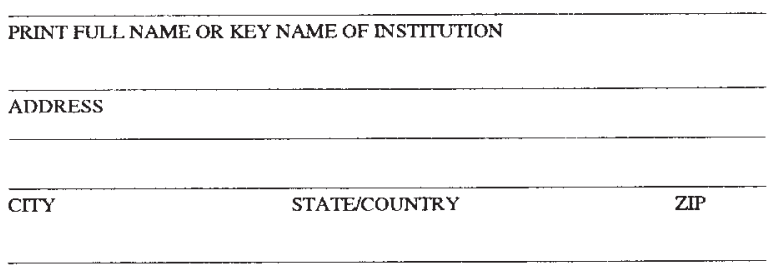

YOUR NAME AND PHONE NUMBER

TITLE

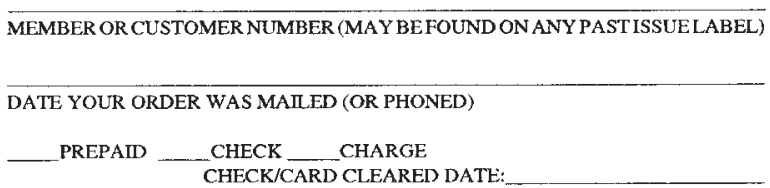

(If possible, send a copy, front and back, of your cancelled check to help us in our research of your claim.)

VOLUME OR YEAR
ISSUES: ___ MISSING DAMAGED
NUMBER OR MONTH

$\underline{2.20}$

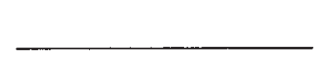

Thank you. Once a claim is received and resolved, delivery of replacement issues routinely takes 4-6 weeks.

(TO BE FILLED OUT BY APA STAFF)

DATE RECEIVED:

ACTION TAKEN:

STAFF NAME:
DATE OF ACTION:

INV. NO. \& DATE:

LABEL NO.\& DATE:

Send this form to APA Subscription Claims, 750 First Street, NE, Washington, DC 20002-4242

PLEASE DO NOT REMOVE. A PHOTOCOPY MAY BE USED. 